Original Research Paper

\title{
Effect of Application of Standard Operating Procedure and Work Motivation to Occupational Accident on Coal Mine Employees
}

\author{
${ }^{1}$ Aprizal Satria Hanafi and ${ }^{2}$ Qomariyatus Sholihah \\ ${ }^{I}$ Alumni of Public Health Study Program, Medical Faculty, Lambung Mangkurat University, Indonesia \\ ${ }^{2}$ Medical Faculty, Lambung Mangkurat University, Indonesia
}

Article history

Received: 14-09-2016

Revised: 20-01-2017

Accepted: 25-01-2017

Corresponding Author: Aprizal Satria Hanafi Alumni of Public Health Study Program, Medical Faculty, Lambung Mangkurat University, Indonesia $\mathrm{Ph}:+6285348915251$

Email: aprizalsatriahanafi@gmail.com

\begin{abstract}
Mining industry is one of the most high risk jobs, thus requiring the application of standard operating procedure in every phase of the work. Based on the preliminary study at PT. Darma Henwa, Site Asam-Asam Coal Project there were 126 cases of occupational accidents in 2012 and 22 cases of occupational accidents in 2013. Several studies have shown, do not apply standard operating procedure and low work motivation are cause of occupational accidents. This study aims to clarify the effect of application of standard operating procedure and work motivation to occupational accidents on employees hauling part. This research is observational analytic method with cross sectional design. The study population was all employees hauling part. Sampling was done by purposive sampling technique. Thus obtained 64 samples of the research. The research instrument use questionnaires. The results of research shows significant effect of application of standard operating procedure and work motivation to occupational accident. Company are expected to conduct strict monitoring of application of standard operating procedures by employees. Application of safety sharing or safety talk is expected to continue and improve safety behavior of employees.
\end{abstract}

Keywords: Standard Operating Procedure, Work Motivation, Occupational Accident, Hauling, Mining

\section{Introduction}

Health Law of Republic Indonesia No. 36 of 2009 on Health in Chapter XII of the health work article 164 paragraph 1 mentions the efforts made to ensure the occupational health of workers in order to live healthy and free of health problems and the adverse effects caused by work (Law of Republic Indonesia No. 36 of 2009). Government requires to all companies in Indonesia to implement Law No. 1 of 1970 about Occupational Health and Safety (OHS) as an effort to control the risk factors of potential hazards in the workplace (Law of Republic Indonesia No. 1 of 1970).

According to the Ministry of Manpower and Transmigration of Indonesia (2011) there were 96,314 cases of occupational accidents, as many as 2,144 people died and 42 disability. The Indonesian government emphasized the importance of OHS in the workplace because work accidents not only lowers labor productivity, but also causing death (Delgado et al., 2015; Alizadeh et al., 2015).

Industrial development is happening in Indonesia, one of them is coal industry. Based on data of Country Coal Mine, Indonesia is one of the 10 countries in the world's largest coal producer. This makes coal mining companies in Indonesia are competing to increase production capacity. Increased production capacity will increase the risk of work (Syahrir et al., 2013).

It is based on the fact that the mining industry, using the method of open cut mining or underground mining is one of the most high-risk job. This is due to the mining sector there are various risk factors that could cause injury, accidents, property damage, or death. In the mining industry there are several risks including fire, coal sparks, coal dust which can cause respiratory problems, noise, explosives, poisonous substances and landslides (Yan et al., 2015; Laney and Weissman, 2014; Cui et al., 2015; Mkpuma et al., 2015). 
The mining industry would require SOP in every phase of work. The first stage in coal mining is the preparation phase. At this stage will be built mining road for transportation of coal. The second stage is land clearing, at this stage is done by cutting the shrubs and trees that are large. The tools used are usually the Ripper bulldozer with the help of chainsaw for felling trees with diameter greater than $30 \mathrm{~cm}$. The third stage is stripping. At this stage, the removal of land to save the land from being damaged so that they have an element of pristine land, so the land can be used and replanted during reclamation. The shelled land can be moved to a temporary storage area or directly transferred to the pile. It depends on the planning of the company. The fourth stage is overburden stripping. When the material is soft rock, overburden excavation is carried out free. However, if the material is hard rock, the first demolition by blasting method. The fifth stage is coal getting, at this stage must be subjected to dry coal activities to clean impurities from the coal face in the form of residual soil cover, as well as other impurities that form the precipitation agent (surface water, rainwater, avalanches). The sixth stage is hauling coal. Coal hauling covers 2 things, transport from the mining area to Stockpile/Temporary Stockpile and transporting waste/overburden to dump area (either in the form of top soil/humus or overburden). The last stage is reclamation. This activity is done to improve the mine land after mining. Aims to improve the reclamation of mine land for environmental preservation and risk mitigation mining. The final goal of the plan is to ensure reclamation of mine land is returned to the productive use (Korol et al., 2014; Zulkarnain et al., 2014; Xiao et al., 2014; Wickham et al., 2013).

Application of SOP will reduce the level of errors and omissions that may be performed by a worker in carrying out the task (Spangenberg and Minnit, 2014). This is in line with Puji and Hariono Research (2011), someone who did not apply sop in work will increase the risk of occupational accidents (Puji and Haryono, 2011; Sholihah and Soewandi, 2014). In addition to the application of SOP, less work motivation is another factor that can lead to accidents. Lack of motivation will affect a person's morale. Safe behavior will be made if someone has high work motivation (Ying et al., 2012).

PT Darma Henwa Asam-Asam Coal Project is a general mining contractor services company that was founded in 1991. Since its inception, the company has carved out a reputation as a reputable mining contractor in Indonesia, a provider of expertise in the field of mining heavy equipment, civil works and maintenance of mining equipment. PT Darma Henwa Asam-Asam Coal Project has given instructions to all employees to implement SOP, but in reality there are employees who do not implement SOP. Based on the preliminary study on PT Darma Henwa Asam-Asam Coal Project there were 126 cases of occupational accidents in 2012 and 22 cases of occupational accidents in 2013. Department of operator system is part of highest occupational accidents, namely 17 cases (77\%) in 2013 (PT. Darma Henwa Tbk, 2013a).

In 2013, work accidents most often occur on the hauling road. There were 6 cases of occupational accidents (27\%). (PT. Darma Henwa Tbk, 2013b). Hauling is a stage of transportation of coal that has been processed according to the required size, then transported to the port by trucks with a capacity of 25-30 tons (PT. Darma Henwa Asam-Asam Coal Project, 2014).

Based on the above background, research shoud be conducted to explain the effect of application of standard operating procedures and work motivation to the occupational accidents on employees hauling part at PT. Darma Henwa Asam-Asam Coal Project.

\section{Materials and Methods}

This research is analytic observational with cross sectional study design (Chandra, 2008). The study was conducted with the approval and support of the School of Public Health, Lambung Mangkurat University, PT. Darma Henwa Asam-Asam Coal Project and all employees hauling part.

The total number of employees at PT. Darma Henwa Asam-Asam Coal Project is 801 people. The study population is all employees hauling part as many as 78 people (PT. Darma Henwa Tbk, 2013a). Sampling technique used is purposive sampling (Siswanto, 2013). The inclusion and exclusion criteria in this study were employees hauling part, the employees were actively working (not sick, do not leave or no holiday). In this study obtained 64 respondents who qualify inclusion and exclusion criteria.

The instrument in this study was a questionnaire to identify application of SOP, work motivation and occupational accidents, which has been tested for validity and reliability before research among respondents with similar jobs in other mining companies.

Questionnaire of application of SOP and work motivation were measured using a Likert scale with four categories. Respondents were given a score of 1 for Strongly Disagree (SD), a score of 2 for disagree (D), a score of 3 for agree (A) and a score of 4 for Strongly Agree (SA). While the questionnaire of occupational accidents measured by checklist sheet to know what kind of accidents experienced by respondents. Respondents who had an occupational accident in any type of occupational accidents will be given a score of 0 and given a score of 1 if does not have accidents on any type of occupational accidents.

Categorizing the application of SOP and work motivation to do with the cut of point method to 
calculate the number of respondents by questionnaire (Barua, 2013). The number of questions of the variable application of SOP and work motivation each totaled 15 items. Calculation category is calculated by knowing in advance the possibility of the greatest value (if the respondents answered all questions with a selection of items strongly agree) and the smallest value (if the respondent answered all items with the option strongly disagree) to determine the range of categories. Total maximum value is $15 \times 4=60$, while the minimum value is $15 \times 1=15$. So that can know the grade span is $60-15$ / amount of class $(3)=45 / 3=15$.

Category application of SOP is:

1. Application of SOP is low if scores: $15-29$

2. Application of SOP is moderate if scores: $30-44$

3. Application of SOP is good if scores: $45-60$

Category of work motivation is:

1. Work motivation is low if scores: $15-29$

2. Work motivation is moderate if scores: $30-44$

3. Work motivation is high if scores: $45-60$

Category of occupational accidents is calculated by counting the number of accidents. Number of questionnaires amounted to 15 items. If ever an accident was given a score of 0 and respondents who did not have an accident was given a score of 1 . Total maximum value is $15 \times 1=15$, while the minimum value is $15 \times 0=0$. So that can know the grade span is $15-0 /$ number $(3)=15 / 3=5$.

Category occupational accidents is:

1. Occupational accidents is high if scores: 0-4

2. Occupational accidents is moderate if scores 5-9

3. Occupational accidents is low if scores 10-15
The independent variables in this study are the application of standard operating procedures and work motivation in PT. Darma Henwa Asam-Asam Coal Project, while the dependent variable in this study is the occupational accidents.

Data analysis was performed using statistical computer programs and data analysis in this study can be described as follows:

\section{Univariate Analysis}

Data are collected, processed and analyzed by descriptive data for the variables presented in frequency distribution table.

\section{Bivariate Analysis}

The statistical methods used in this study is spearman rank correlation test with significance level $\alpha=0.05$ (Musafaah, 2013) to determine a significant effect on the application of SOP and work motivation to the occupational accidents.

\section{Results}

\section{Univariate Analysis}

Table 1 shows $51.2 \%$ of respondents aged between $30-40$ years. All respondents were male and $62.5 \%$ received his high school education, only $4.8 \%$ were educated to degree. About $90.6 \%$ of respondents were married. About $59.4 \%$ of respondents have periode of working less than or equal to 5 years and $40.6 \%$ of respondents have periode of working more than 5 years.

The focus of this research is the application of SOP, work motivation and occupational accidents. Based on the results of 64 respondents, the obtained frequency distribution of the application of SOP, work motivation and occupational accidents by employees hauling part can be seen in Table 2 .

Table 1. Description of respondents based on socio-demographic

\begin{tabular}{llc}
\hline Characteristics & Frequency & Precentage \\
\hline Age (Years) & & $29.7 \%$ \\
$20-30$ & 19 & $51.2 \%$ \\
$31-40$ & 33 & $15.6 \%$ \\
$41-50$ & 10 & $3.12 \%$ \\
$>50$ & 2 & $100 \%$ \\
Gender & 64 & $0 \%$ \\
$\quad$ Male & 0 & $0 \%$ \\
Female & 0 & $32.8 \%$ \\
Education Level & 21 & $62.5 \%$ \\
$\quad$ Elementary School & 40 & $4.8 \%$ \\
$\quad$ Middle School & 3 & 90,6 \\
$\quad$ High School & 58 & $9,4 \%$ \\
$\quad$ College & 6 & $59,4 \%$ \\
Marital Status & & \\
$\quad$ Married & 38 & $40,6 \%$ \\
$\quad$ Not Married & 26 & $100 \%$ \\
Periode of Working & 64 & \\
$\quad$ 5 Years & &
\end{tabular}


Table 2. Description of respondents based on application of SOP, work motivation and occupational accidents

\begin{tabular}{llc}
\hline Variable & Frequency & Precentage \\
\hline Application of SOP & & \\
$\quad$ Moderate & 10 & $15.6 \%$ \\
$\quad$ Good & 54 & $84.4 \%$ \\
Work Motivation & 19 & $29.7 \%$ \\
$\quad$ Moderate & 45 & $70.3 \%$ \\
$\quad$ High & 50 & $78.1 \%$ \\
Occupational Accidents & 12 & $18.8 \%$ \\
$\quad$ Low & 2 & $3.1 \%$ \\
$\quad$ Moderate & 64 & $100 \%$ \\
$\quad$ High & &
\end{tabular}

Table 3. Spearman rank correlations test results

\begin{tabular}{llll}
\hline Variable & $*$ p-value & $* *$ Correlation coefficient $(\mathrm{r})$ & Information \\
\hline $\begin{array}{l}\text { Effect of application of SOP } \\
\text { to occupational accidents }\end{array}$ & 0.002 & 0.776 & $\begin{array}{l}\text { There is significant effect of application } \\
\text { of SOP to occupational accidents }\end{array}$ \\
$\begin{array}{l}\text { Effect of work motivation } \\
\text { to occupational accidents }\end{array}$ & 0.011 & 0.814 & $\begin{array}{l}\text { There is significant effect of work } \\
\text { motivation to occupational accidents }\end{array}$ \\
\hline
\end{tabular}

$* \mathrm{p}$ value $<0.05$ is significant

$* *$ correlation coefficient close to 1 , the correlation become stronger

Table 2 shows that the number of respondents with moderate application of SOP are 10 respondents $(15.6 \%)$ and good application of SOP are 54 respondents $(84.4 \%)$. Application of SOP is one way to prevent occupational accidents. Based on research data and direct observation can be seen, most employees are already applying SOP. The number of respondents with moderate work motivation are 19 respondents $(29.7 \%)$ and high work motivation are 45 respondents (70.3\%). Motivation is very important to be considered by the management, if they want every employee can make a positive contribution to the achievement of corporate goals. The number of respondents with low occupational accidents are 50 respondents (78.1\%), moderate occupational accidents are 12 respondents $(18.8 \%)$ and high ccupational accidents are 2 respondents (3.1\%). Accidents do not happen by chance. Therefore the causes of accidents should be investigated and discovered, so that accidents can be prevented and will not be repeated.

\section{Bivariate Analysis}

The bivariate analysis conducted correlation test to determine the effect of application of SOP and work motivation (independent variable) against occupational accidents on employees Hauling part (dependent variable). The test used is Spearman Rank Correlation. The result of Spearman Rank can be seen in Table 3.

\section{Discussion}

Spearman Rank Test result with a 95\% confidence level, to see the effect of the application of SOP against occupational accidents on the employees Hauling part. $\mathrm{P}$ value of statistical test results is $0.002(p<0.05)$, which means there is significant effect between the application of SOP and occupational accidents on the employees Hauling part. The $r$ value $=0.776, \mathrm{r}$ value indicates that there is a strong effect between application of SOP to occupational accidents. Given the strong effect of the application of SOP in preventing occupational accidents. This means the potential for occupational accidents will increase without applying SOP.

The most common cause of occupational accidents is to do a job without clear work instructions and do not applying SOP (Spangenberg and Minnit, 2014). Do not applying SOP in the works is a direct cause of occupational accidents (Moan and Soewandi, 2015). Many employees who underestimate the risks of work, so do not use a safety device despite being listed in the SOP. In the operation of heavy equipment when employees do not obey the signs will lead to occupational accidents (Shamsuddin et al., 2015). For example, in the workplace there are red triangle sign, which means it must pause when driving heavy equipment at a crossroads. However, during this time when the road conditions were empty, these signs are not obeyed. Whereas other heavy equipments may appear suddenly (Chimamise et al., 2013).

This is in line with Kurniawati research (2014), carrying out the work according to SOP will reduce the risk of occupational accidents. Nurses at the hospital perinatology unit Tugurejo Semarang injured at work in the form of needle-stick because it does not carry out the work according to SOP. The nurse did not close the syringe after used (Kurniawati, 2014). 
Factors causing the accident consisted of the basic causes and direct causes. The basic cause of accidents are the lack of ability (physically and mentally), lack of knowledge, lack of skills, physical and mental stress and lack of motivation (Sohail and Rehman, 2015; Wenwen et al., 2011; Zhang, 2014). While the direct cause of accidents are operate equipment without permission, operate the equipment beyond the speed limit, using a heavy equipment that is incomplete, using a heavy equipment that is damaged, do not wear Personal Protective Equipment (PPE), smoking in forbidden places, making the safety equipment is not working, replace protective working position is not correct, using a tool incorrectly, using excessive force, do not follow work procedures and ignoring orders/rules/ban (Boniface et al., 2013; Arbak, 2015; Ali et al., 2010).

Provision of detection devices and the installation of signs in the mining is necessary to provide a rule in the drive for employees. Required risk control by monitoring and review of the risk of harm. Hazard control can be made by the employees report any hazardous conditions to the company management or supervisor (Chan and Annie, 2012). Procurement signs in the company's working environment has been made by the company. Employees can also report their findings unsafe conditions to the company management (PT. Darma Henwa Asam-Asam Coal Project, 2014).

The application of SOP in the regulation of traffic is an aspect that must be considered. Traffic accidents are the types of potential hazards is often the case. Various efforts have been made in the form of management rules to be followed by all employees Hauling part. The regulation of mandatory use of seatbelts, turn on lights, monitoring the radio, setting the maximum speed limit, mounting a flag on the front of the heavy equipment as a signs. However, in spite of it all prudence and adherence operator is the main key to a traffic accident does occur mine (PT. Darma Henwa Asam-Asam Coal Project, 2014).

Wahidin research describes the use of seat belts can minimize the risk of accidents. When a collision occurs, seat belt will hold the body from hitting the steering wheel or hitting the windshield. In the event of a collision from the front, the car will stop within 0.05 or 0.02 seconds, if not wearing a seatbelt will be very hard collision (Wahidin, 2008).

In addition to avoiding the risk of occupational accidents each operator is obliged to examine the component units of heavy equipment operated, if found damage to the component units of heavy equipment can be repaired before it is operated (Dash et al., 2015). Another important factor in the application of SOP is the current working conditions of employees, the operator should be ergonomic. Heavy equipment condition to be adjusted by the employees to operate heavy equipment to ensure the comfort of employees while driving. This needs to be done to prevent fatigue and occupational diseases such as musculoskeletal disorders (Hermanus, 2007; Esterhuizen and Gurtunca, 2006).

One way to control occupational accidents is a technical control. Technical control is done by eliminating the risk or controling the hazards technically. If the source of hazard control can not be done, the use of PPE should be done (Zhang et al., 2011). PPE required by mine employees are safety shoes, safety glasses, safety helmets, masks, reflective vests and ear plugs (Kilinc et al., 2014).

The use of PPE is the last stage to control occupational accidents and occupational diseases. Nonetheless, the use of PPE would be very important if the technical and administrative controls have done optimally but the potential risks still high. The amount of benefits from the use of PPE does not ensure that all mine employees wear PPE, there still many mine employees do not wear PPE because it was in safe condition and not supervised by supervisor (Kanungo et al., 2015).

Spearman Rank Test Results with a 95\% confidence level, to see the effect of work motivation against occupational accidents on the employees Hauling part. $\mathrm{P}$ value of statistical test results is $0.011(\mathrm{p}<0.05)$, which means there is significant effect between work motivation and occupational accidents on the employees Hauling part. The $r$ value $=0.814, \mathrm{r}$ value indicates that there is a strong effect between work motivation and occupational accidents. This indicates if the work motivation is low, the risk of occupational accidents will increase.

This is in line with Wianjani research (2010) who did research on the cement industry workers. The results shows one of the fundamental causes of the occupational accidents is lack of motivation (Wianjani, 2010). High motivation will encourage workers to reach safety in work. Low employee work motivation will make the employee do not concentrating on work. Do not concentrate in operating heavy equipment can cause occupational accidents. Someone who has a high work motivation will work well to achieve the goals (Sarna, 2015; Kong and Cai, 2015).

Employees are important components that support the achievement of corporate goals. To develop positive attitudes, motivation of employees should be increased. In this case both external and internal motivation (Al-Haadir et al., 2013).

Motivation of an employee in a work influenced by several needs, especially the needs of security. Need for security is on the second level of the pyramid of needs after the biological needs. It was concluded that safety needs is an absolute requirement must be met. Safety needs include a guarantee of occupational safety, health insurance, salary, pension benefits or severance, creating a sense of security to the employees and the protection of employees in the work (Cheng et al., 2012; Nielsen, 2014). 
High employee motivation in the work is a resource for the company to produce high quantity and quality of work. Without motivation, a person can not fulfill his duties. Even if an employee has a good operational capability, if it does not have the motivation to work, the work will not satisfy. Motivation of employees determine the success in achieving corporate goals (Alimuddin, 2012).

In this study, the majority of employees (70.3\%) have a high motivation. This is due to factors that encourage high employee motivation such as salary/income, honoraria in accordance with the work, the cost of travel when the leave and incentives received. The higher incentives earned by the employees, will increase people's motivation to work. High employee motivation will be a competitive advantage for the company. These advantages, the human resources company will be able to follow the changes and developments in the market, according to consumer demand (Al-Nsour, 2012).

The basic motivation for most people work is to earn a living. When someone uses the knowledge, skills, efforts and time to work then that person expects rewards or salary (Nurmiyati, 2011; Gohari et al., 2013).

According to Sumarna research (2012) motivation influence the behavior of people in work, especially related to the application of SOP and use of PPE during work (Sumarna, 2012). The company must provide PPE free of charge to all employees to raise the motivation of employees in the use of safety boots, safety helmet, clothes fitted schotlite. The use of PPE adapted to the type of work to ensure safety during work (Navidian et al., 2015).

Unhealthy and unsafe employees conditions will reduce the motivation of employees, this will increase the number of employees who stopped working. Meanwhile, when the working conditions are safe and comfortable will increase the motivation of employees to work better. High motivation will make the employees working with applying SOP to prevent occupational accidents (Zhu and Ping, 2009).

According to Ying et al. (2012), award will motivate employees to work well. Award is a recognition of the company towards achievement of employees. This will lead to employee satisfaction. Employees will work better to prevent occupational accidents (Ying et al., 2012; Utoro and Gustomo, 2014).

The study looking for the application of SOP in the mining company. Measurement of the application of SOP is not only determined by the answers of the questionnaire, but also through direct observation when employees are work. While limitations in this study is the data retrieval process is not carried out simultaneously. Thus enabling the provision of information by the respondent before to the prospective respondents.

\section{Conclusion}

Most employees hauling part have good application of SOP, most employees Hauling part have good work motivation, most employees Hauling part has a low occupational accidents. There is a significant effect between application of SOP and occupational accidents, there is a significant effect between work motivation and occupational accidents.

In this study, although the majority of respondents have good application of SOP, sometimes employees did not applying SOP because they feel not in danger, for example, not using a seat belt while driving, not using helmets while driving and driving heavy equipment exceeding the legal speed limit. SOP violations are most often committed by the respondent was driving beyond the speed of heavy equipment and transport coal exceed load limits. This situation often leads to occupational accidents. Required tighter supervision to employees hauling part in applying SOP.

\section{Acknowledgement}

Thanks to Allah SWT for bless. The authors are grateful for the help and guidance of PT. Darma Henwa Asam-Asam and employees hauling part who have been very cooperative and gave the support in conducted this research and Thanks to all stakeholders who support the passage of this research.

\section{Funding Information}

There is no external funding in this study.

\section{Author Contribution}

Aprizal Satria Hanafi: Participate in all research activities, the licenses to the coal mining company, collecting data, analyzing data, contributed to the writing of the manuscript.

Qomariyatus Sholihah: Designing research methods, analyzing data, have contributed to the writing of the manuscript.

\section{Competing Interest}

The Author state that there is no conflict of interest regarding publication of this article.

\section{Ethical Approval}

Ethical approval was not required for this study.

\section{References}

Al-Haadir, S., K. Panuwatwanich and R.A. Stewart, 2013. Empirical analysis of the impacts of ssafety motivation and safety climate on safety behavior. School of Engineering, Griffith Universiity. 
Ali, A.S., S.N. Kamaruzzaman and G.C. Sing, 2010. A study on courses of accidents and prevention in Malaysian Construcion Industry. J. Design Built, 3: 95-104.

Alimuddin, I.K., 2012. Influence of motivation to work productivity of employees at PT. Telkom Indonesia, Tbk Branch Makassar. PhD Thesis, Faculty of Economic and Business, University of Hasanuddin, Makassar.

Alizadeh, S.S., S.B. Mortazavi and M.M. Sepehri, 2015. Analysis of occupational accident fatalities and injuries among male group in Iran between 2008 and 2012. Iranian Red Crescent Med. J., 17: 1-6. DOI: 10.5812 ircmj. 18976

Al-Nsour, M., 2012. Relationship between incentives and organizational performance for employees in the Jordanian Universities. Int. J. Bus. Manage., 7: 78-89. DOI: $10.5539 /$ ijbm.v7n1p78

Arbak, P., 2015. Precautions for the prevention of mine accidents and related respiratory emergencies. Turkish Thorac J., 16: S25-S26.

DOI: $10.5152 / \mathrm{ttd} .2015 .007$

Barua, A., 2013. Methods for decision-making in survey questionnaires based on likert scale. J. Asian Sci. Res., 3: 35-38.

Boniface, R., L. Museru, V. Munthali and R. Lett, 2013. Occupational injuries and fatalities in a tanzanite mine: Need to improve workers safety in Tanzania. Pan Afr. Med. J., 16: 1-7.

DOI: $10.11604 /$ pamj.2013.16.120.3420

Chan, A.H.S. and W.Y.N. Annie, 2012. The guessing of mine safety signs meaning: Effects of user factors and cognitive sign features. Int. J. Occupat. Safety Ergonom., 18: 195-208.

DOI: $10.1080 / 10803548.2012 .11076928$

Chandra, B., 2008. Health research method. EGC, Jakarta.

Cheng, Z.H., X. Wang, D.S. Wang and J. Zheng, 2012. Application of dual structure theory on motivating safe behavior of coal mine staff. J. Coal Sci. Eng., 18: 73-79. DOI: 10.1007/s12404-012-0113-0

Chimamise, C., N.T. Gombe, M. Tsimanga and A. Chadambuka, 2013. Factors associated with severe occupational injuries at mining company in Zimbabwe, 2010: A cross-sectional study. Pan Afr. Med. J., 14: 1-5. DOI: 10.11604/pamj.2013.14.5.1148

Cui, Y., S.S. Tian, N. Qiao, C. Wang and T. Wang et al., 2015. Associations of individual-related and jobrelated risk factors with nonfatal occupational injury in the coal workers of shanxi province: A crosssectional study. Plos One, 7: 1-13. DOI: 10.1371/journal.pone.0134367

Dash, A.K., R.M. Bhattcharjee, P.S. Paul and M. Tikader, 2015. Study and analysis of accidents due to wheeled trackless transportation machinery in Indian coal mines - identification of gap in current investigation system. Procedia Earth Planetary Sci., 11: 539-547. DOI: 10.1016/j.proeps.2015.06.056
Delgado, M.G., H.G. Dantes, J.A.F. Nino and E. Robles, 2015. Factors associated with fatal occupational accidents among Mexican Workers: A national analysis. Plos One, 10: 1-19.

DOI: 10.1371/journal.pone.0121490

Esterhuizen, G.S. and R.G. Gurtunca, 2006. Coal mine safety achievements in the USA and the contribution of NIOSH research. J. Southern Afr. Institute Min. Metallurgy.

Gohari, P., A. Kamkar, J. Hossenipour and M. Zohoori, 2013. Relationship between rewards and employee performance: A mediating role of job satisfaction. Interdisciplinary J. Contemporary Res. Bus., 5: 571-597.

Hermanus, M.A., 2007. Occupational health and safety in mining-status, new developments and concerns. J. Southern Afr. Institute Min. Metalurgy, 107: 531-538.

Kanungo, B., G. Thakar and P. Sharma, 2015. Personal protective equipments are last resort of safety. Int. J. Computat. Eng. Manage., 18: 8-15.

Kilinc, F.S., W.D. Monaghan and J.B. Powell, 2014. A review of mine rescue ensembles for underground coal mining in the United States. J. Eng. Fibers Fabr., 9: 174-185.

Kong, F. and Y. Cai, 2015. Human resources and safety performance in China's Coal Mining Firms. Lera Ann. Meet. Proc., 63: 134-147.

Korol, D.B., P. Krawczyk, K.C. Kolarz and M. Turek, 2014. Development of sustainability assessment method of coal mines. J. Sustainable Min., 13: 5-11. DOI: $10.7424 /$ jsm 140402

Kurniawati, W., 2014. Relations practice the application of Standard Operating Procedure (SOP) and the use of Personal Protective Equipment (PPE) and the incidence of occupational accidents in perinatology unit nurses in hospitals Tugurejo Semarang. PhD Thesis, Faculty of Health Dian Nuswantoro University, Semarang.

Laney, A.S. and D.N. Weissman, 2014. Respiratory disease caused by coal mine dust. J. Occupat. Environ. Med., 56: S18-S22. DOI: 10.1097/JOM.0000000000000260

Law of Republic Indonesia No. 1 of 1970 about Safety. Law of Republic Indonesia No. 36 of 2009 about Health. Ministry of Manpower and Transmigration of Indonesia. 2011. Occupational Accident Report in Indonesia.

Mkpuma, R.O., O.C. Okeke and E.M. Abraham, 2015. Environmental problems of surface and underground mining: A review. Int. J. Eng. Sci., 4: 12-20.

Moan, F.A.C.W. and T. Soewandi, 2015. An overview of the causes of work accidents in the komodo's bite workers in komodo national park. Civil Environ. Res., 7: 76-80.

Musafaah, 2013. Textbook of Data Management. Banjarbaru: Public Health Study Program. Faculty of Medicine, Lambung Mangkurat University. 
Navidian, A., Z. Rostami and N. Rozbeheni, 2015. Effect of motivational group interviewing-based safety education on workers' safety behaviors in glass manufacturing. BMC Public Health, 15: 1-7. DOI: $10.1186 / \mathrm{s} 12889-015-2246-8$

Nielsen, K.J., 2014. Improving safety culture through the health and safety organization: A case study. J. Safety Res., 48: 7-17. DOI: 10.1016/j.jsr.2013.10.003

Nurmiyati, E., 2011. Reward and punishment relationship with employee performance on BPRS Harta Insan Karimah. Undergraduate Thesis, Faculty of Sharia, Syarif Hidayatullah State Islamic University, Jakarta.

PT. Darma Henwa Asam-Asam Coal Project, 2014. Standard Working Instruction Coal Hauling Traffic.

PT. Darma Henwa Tbk, 2013a. Company profile and analysis of occupational accidents.

PT. Darma Henwa Tbk, 2013b. Data man power.

Puji, W.R. and W. Hariyono, 2011. Penerapan manajemen keselamatan dan kesehatan kerja (MK3) di instalasi gawat darurat rsu pku muhammadiyah yogyakarta (Application of occupational health and safety management in the emergency department of RSU PKU Muhammadiyah Yogyakarta). J. Kesehatan Masyarakat, 5: 1-7.

DOI: $10.12928 /$ kesmas.v5i1.1084

Sarna, S.G., 2015. A study of the motivational aspects of the employees of Datong Coal Mining Group in Terms of enhancing their performance level and prevent accident in HRM Perspective. Int. J. Recent Res. Commerce Econom. Manage., 2: 61-85.

Shamsuddin, K.A., M.N.C. Ani, A.K. Ismail and M.R. Ibrahim, 2015. Investigation the Safety, Health and Environment (SHE) protection in construction area. Int. Res. J. Eng. Technol., 2: 624-636.

Sholihah, Q. and T. Soewandi, 2014. Correlation implementation of housekeeping and indi vidual factors with accident prevention efforts in IBT Co. Ltd Kotabaru. Walia J., 30: 80-85.

Siswanto, 2013. Health and Medicine Research Method. 1st Edn., Bursa Ilmu, Yogyakarta.

Sohail, M. and C.A. Rehman, 2015. Stress and Health at the workplace-A review of the literature. J. Bus. Stud. Q., 6: 94-121.

Spangenberg, L.C. and R.C.A. Minnitt, 2014. An overview of sampling best practice in African mining. J. Southern Afr. Institute Min. Metalurgy, 114: 91-102.

Sumarna, D.P., 2012. Determinants of use of Personal Protective Equipment (PPE) on printing employee in Makasar. Occupational, Health and Safety Section Faculty of Public Health, Hasanuddin University.

Syahrir, R., J.C. Bongaerets and C. Drebenstedt, 2013. The future of Indonesian mining activities after the implementation of law number 4 of 2009 concerning mineral and coal mining (The new mining law). IMRE J., 7: 21-30.
Utoro, D.T. and A. Gustomo, 2014. Analysis of employee engagement in PT Kaltim Prima Coal, Indonesia. J. Bus. Manage., 3: 475-482.

Wahidin, A., 2008. The influence of the use of safety belt against the fatality rate of accidents and the severity of the accident (A case study of a motorway crash parts A, B, C Branch Semarang). MSc. Thesis, Graduate Program, University of Diponegoro, Semarang.

Wenwen, S., J. Fuchuan, Z. Qiang and C. Jingjing, 2011. Analysis and control of human error. Procedia Eng., 26: 2126-2132. DOI: 10.1016/j.proeng.2011.11.2415

Wianjani, D., 2010. Qualitative analysis of the relationship between the results of the risk analysis work safety with the incidence of accidents that have occurred in workers at the facility shedder unit PT Holcim Indonesia Tbk Year 2010. MSc. Thesis, Faculty of Medicine and Health Science, Syarief Hidayatullah Islamic State University, Jakarta.

Wickham, J., P.B. Wood, M.C. Nicholson, W. Jenkins and D. Druckenbrod et al., 2013. The overlooked terrestial impacts of mountaintop mining. Biosci. Oxford J., 63: 335-348. DOI: $10.1525 /$ bio.2013.63.5.7

Xiao, W., Z. Hu and Y. Fu, 2014. Zoning of land reclamation in coal mining area and new progresses for the past 10 years. Int. J. Coal Sci. Technol., 1: 177-183. DOI: $10.1007 / \mathrm{s} 40789-014-0024-3$

Yan, C., S.S. Tian, N. Qiao, C. Wang and T. Wang et al., 2015. Associations of Individual-related and jobrelated risk factors with nonfatal occupational injury in the coal workers of shanxi province: A crosssectional study. Plos One, 10: 1-13. DOI: 10.1371 /journal.pone.0134367

Ying, L., H. Zhijia and L. Laianbao, 2012. Motivation mechanism of accident prevention in coal mine. Procc. Eng., 43: 174-179. DOI: $10.1016 /$ j.proeng.2012.08.030

Zhang, J.S., S.S. Gao, J. Tao and P.P. He, 2011. Study on unsafe behavior pre-control method based on accidents statistic. Proc. Eng., 26: 1964-1969. DOI: 10.1016/j.proeng.2011.11.2391

Zhang, W., 2014. A study on the identification of factors affecting the safe working state of coal miners. J. Chem. Pharmaceutical Res., 6: 641-646.

Zhu, J. and M.X. Ping, 2009. Safety evaluation of human accidents in coal mine based on ant colony optimization and SVM. Proc. Earth Planetary Sci., 1: 1418-1424. DOI: 10.1016/j.proeps.2009.09.219

Zulkarnain, B. Joy, P. Tuhpawanan and I. Prawira, 2014. Soil soil erosion assessment of the post-coal mining site in kutai kartanagera district, east kalimantan province. Int. J. Sci. Eng., 7: 130-136. DOI: $10.12777 /$ ijse.7.2.130-136 